\title{
The Effect of US Foreign Policy on the Relationship Between South and North Korea: Time Series Analysis of the Post-Cold War Era
}

\author{
Jong-Han Yoon
}

In this study, I examine the effect of US foreign policy on the relationship between South Korea and North Korea. In particular, I analyze whether two different foreign policy approaches-the hard-line approach and the soft-line approach-have played a role in advancing or slowing steps toward peace in the Korean peninsula. I use the Integrated Data for Events Analysis dataset for the period 1990-2004. By employing a Vector Autoregression model, which analyzes the behavioral patterns of South and North Korea and the United States, I find that US foreign policy affects the relationship between the two Koreas by affecting North Korea's behavior toward South Korea. The triangular relationship among the United States, North Korea, and South Korea shows a reciprocal behavior pattern. This finding suggests that a soft-line and reciprocal US foreign policy toward North Korea is critical to maintaining peace in the Korean peninsula. KEYWORDs: hard-line, reciprocity, triangular relationship, South Korea, North Korea, China, US foreign policy, peace, Korean peninsula, behavioral patterns

AS A DIVIDED NATION, THE KOREAN PENINSULA IS ONE OF THE MOST HEAVILY militarized regions in the world. During the Cold War era, the border separating North and South Korea represented the fault line between two ideological camps. Since the end of the Cold War, the relationship between the two Koreas has improved somewhat as a result of two interKorean summits reuniting separated families, tours for South Koreans to Keumkang mountain in North Korea, and the creation of a joint industrial complex in the North Korean city of Kaesung. However, in spite of these improved relations between South and North Korea, military tension between the two Koreas remains. The recent North Korean artillery attack, which killed two marines and two civilians on the South 
Korean island of Yeonpyeong in November 2010, and the sinking of a South Korean naval vessel, the Cheonan, in March 2010 demonstrate the volatility of the military situation. Although both South and North Koreans aspire to attain a peaceful relationship and, ultimately, the unification of Korea, military confrontation between the two Koreas exacerbates the humanitarian issues of separated families and excessive military spending.

For maintaining and promoting a peaceful relationship between South and North Korea, the role of US foreign policy has been critical. Since the armistice agreement between North Korea and the United States in 1953, the US policy of military deterrence against North Korea has been a main buttress for the security of the Korean peninsula and the northeast Asian region. During the Cold War, the focus of US policy in the Korean peninsula was on maintaining the balance of power, manifested by the presence of US military bases. Although there have been occasional diplomatic efforts toward a peace settlement in the Korean peninsula, such as the South-North joint declaration in 1972, those were considered secondary to the policy of deterrence. Indeed, those diplomatic efforts were considered by many to be little more than political rhetoric.

Since the end of the Cold War, the aspiration of attaining a sustainable peace settlement in the Korean peninsula has grown among Koreans, as the main US foreign policy objective of deterring the spread of communism has dissipated and the military capacity and economic power of South Korea has surpassed that of North Korea. Starting with the Northern Policy of the Roh Tae-woo administration, South Korea has attempted to open discourse on Korean reunification and normalization of relations with socialist states. Subsequent South Korean administrations have pursued the relaxation of military tensions and the formation of a peace regime ${ }^{1}$ in the peninsula.

In seeking a sustainable peace settlement and a peace regime in the Korean peninsula, the role of US foreign policy toward the peninsula is very important not only because of US military deployments and exercises in South Korea but also because of the broader US foreign policy stance toward North Korea. Since the mid-1990s, military tension in the Korean peninsula has increased due to North Korea's nuclear weapons development program. The United States has been the main actor in dealing with North Korea's nuclear program, and it is plausible that US foreign policy in the Korean peninsula affects the relationship between the two Koreas, either directly or indirectly.

In this study I examine the effects of US foreign policy on relations between South Korea and North Korea. In particular, I analyze how two 
different US foreign policy approaches - the hard-line approach and the soft-line approach-have played a role in progressing or regressing the steps toward a peaceful relationship between South and North Korea. How does US foreign policy affect the level of conflict between South and North Korea? What are the similarities and differences between the effects of the two foreign policy approaches on the alleviation of military tension and the promotion of a peaceful relationship between the two Koreas?

In addition to these main research questions, I also explore the effect of foreign policy interactions between the United States and South Korea. Whether the foreign policies of these two governments are compatible could be another factor in promoting a peaceful relationship between South and North Korea. What has been the effect of the congruence of US foreign policy with that of South Korea toward North Korea? And what is the effect of a hard-line or soft-line approach in US foreign policy when it is not coordinated with South Korean foreign policy toward North Korea?

To answer these questions, I first consider the theoretical literature on the effects of hard-line and soft-line approaches as well as the effects of outside powers and triangular relationships in which coordination may influence outcomes. I then conduct a statistical analysis of US foreign policy in the Korean Peninsula during the post-Cold War era using the Integrated Data for Events Analysis (IDEA), which measures state interactions in the peninsula. I employ a VAR (Vector Autoregression) model to analyze the effect of US foreign policies on the relationship between the two Koreas for the period 1990-2004. I find that soft-line approaches, which emphasize reciprocal strategic responses, have promoted peaceful relations between the two Koreas. I also find that foreign policy disparity between the United States and South Korea toward North Korea could imperil peace in the Korean peninsula by leading to a hostile US foreign policy toward North Korea and, as a consequence, North Korean hostile behavior toward South Korea.

\section{Theories of Strategic Response Patterns and Cooperation Among States}

Theories of strategic response patterns to elicit cooperation-hard-line approaches and reciprocity - have focused mostly on bilateral relations between the superpowers during the Cold War era. The differences between the two approaches are based on a state's image of its opponents, its selfimage, and its strategic preferences (Snyder and Diesing 1977, 298-310). 
Hard-liners assume that their opponents are calculating and aggressive bluffers. They believe that opponents are likely to take advantage of any sign of weakness but are also likely to pull back if one shows a firm stance (Snyder and Diesing 1977, 308-309). Therefore, the appropriate strategy to induce cooperation is a coercive strategy, such as deterrence or even bullying. In particular, the coercive strategy has been considered effective in a "chicken game" situation (Snyder and Diesing 1977, 118-122).

While deterrence and bullying rely on shows of strength, their aims are different. The primary aim of deterrence is to prevent military action-in particular, an armed attack. Deterrence, therefore, focuses on revealing information on the defender's policies and capabilities to persuade opponents not to initiate aggressive action. Although deterrence includes conditional threats ("if you attack, I will respond"), it refrains from directly threatening opponents. The intent of bullying, by contrast, is to make the opponents look weak. Thus, a state intimidates another for the sake of humiliation (Greffenius and Gil 1992, 40; Huth and Russett 1990, 469-472). Therefore, bullying can be regarded as a more aggressive strategy.

The main problem with employing a hard-line strategy is that it presents the risk of escalating a conflict into a situation that could eventually yield low payoffs to both sides, especially when both sides have roughly equal strength (Patchen 1987, 167). Studies have revealed that there is at best weak empirical support for the notion that a hard-line approach, particularly a bullying strategy, fosters cooperation, especially when compared to the effects of other strategies for promoting cooperation. Regarding interstate relations, R. J. Leng and H. G. Wheeler (1979) find that nine out of thirteen cases where a bullying strategy was employed resulted in war between nations. This finding partially confirms the negative effect of the use of bullying if eliciting cooperation from an adversary is the goal.

With regard to the case of the Korean peninsula, hard-liners have advocated using a coercive strategy such as isolation, containment, economic sanctions, and even military attacks toward North Korea in response to its nuclear weapons and ballistic missile tests. They have advocated a hawkish position because they believe the North Korean regime has fundamentally "evil" intentions to develop and sell nuclear weapons and missile technology. They believe North Korea is attempting to extort concessions by blackmail and brinksmanship (Cha and Kang 2003, 1-5).

The main concern of the hard-line strategy with regard to the North Korean issue is consistent with the literature: the risk of escalation to 
military conflict or war. Opponents of the hard-liner position fear that coercive policies might not have the intended effects and could rather lead to a full-scale war in the peninsula, resulting in millions of civilian deaths (Moon 2008; Carpenter and Bandow 2004, 89; O'Hanlon and Mochizuki 2003). ${ }^{2}$ Michael O'Hanlon and Mike Mochizuki argue that the lack of information about the exact locations of North Korea's nuclear facilities would make the chance of a successful surgical strike against those facilities rather low, and such an attack could result in a war in the peninsula. They also indicate that economic sanctions against North Korea could lead to its increasing weapons sales in order to sustain its economy. This would represent another unintended adverse consequence of a hard-line policy. Similarly, Ted Carpenter and Doug Bandow (2004) contend that a military attack might not destroy all nuclear facilities in North Korea and could trigger a war. Carpenter and Bandow add that other coercive measures, such as economic sanctions, might not produce any significant policy changes by North Korea. After all, that regime has managed to sustain its destitute situation for decades.

Those advocating an approach of reciprocity, in contrast to those advocating a hard-line approach, argue that a reciprocal response pattern, or "tit-for-tat" strategy, can promote the evolution of cooperation among states faced with a prisoner's dilemma situation. That is, in a repeated game situation, a reciprocal response pattern, which responds with cooperation against an opponent's cooperation and competition in response to competition, is effective in eliciting an adversary's cooperation and in producing favorable outcomes (Axelrod 1984). The effectiveness of the reciprocal strategy has been widely supported empirically in dispute situations between states (Goldstein et al. 2001; Greffenius and Gill 1992; Leng 1984; Leng and Wheeler 1979) and within states (Shellman, Reeves, and Stewart 2007; Moore 1998).

The primary strength of the reciprocal strategy is that it avoids unnecessary conflicts as long as the opponent reciprocally cooperates. It also avoids the problem of exploitation from the opponent by reciprocating retaliation when the opponent does not cooperate (Axelrod 1984; Patchen 1987, 175).

However, there are some limits to the applicability and effectiveness of a reciprocal strategy in international politics. First, the prisoner's dilemma situation is not as common a situation in international politics as is often thought (Russett 1983, 115), and the evolution of cooperation only works under a specific form of prisoner's dilemma that is rarely found in an international conflict situation (Bueno de Mesquita and Lalman 1992, 95-144; Goldstein et al. 2001). Second, the use of a reciprocal 
strategy is limited when there is power asymmetry between states. It is difficult to develop cooperation if power between states is imbalanced because more powerful states do not fear the adversary's retaliation (Rubin and Brown 1975; Zartman 1997; Goldstein et al. 2001). Third, it is difficult to change the image of the enemy, and international cooperation does not easily evolve even with reciprocal strategies (Larson 1988; Tetlock 1998 ; Goldstein et al. 2001). Fourth, when cooperative initiatives are absent, reciprocity might become "locked in"-but locked in on mutual competition or "defection" that generates an endless arms race (Patchen 1987, 176; Goldstein et al. 2001, 591). Therefore, the question arises of how to develop reciprocal positive action if a pattern of mutual resistance or hostility has already been established (Boyle and Lawler 1991; Osgood 1962).

Regarding the case of the North Korean nuclear program, soft-liners have suggested negotiating with North Korea. The goal of negotiations is to persuade North Korea to terminate its nuclear program and submit to rigorous inspections of its nuclear facilities in return for energy supplies, food aid, security guarantees, normal diplomatic relations, and an end to economic sanctions (Moon 2008; Carpenter and Bandow 2004; O'Hanlon and Mochizuki 2003). This position is based on soft-liners' perception that North Korea's hostile actions such as testing nuclear weapons and missiles mainly come from its military insecurity and economic hardship. According to this view, North Korea has used such belligerent actions to draw international attention and bring about negotiations that could provide it with the security guarantees and economic aid it desires and needs (Cha and Kang 2003, 1-5; Park 2002; Snyder 1999).

A major advantage of the reciprocal strategy in the case of the North Korean nuclear weapons program is that it can avoid the escalation of militarized disputes to a full-scale war in the peninsula as long as North Korea and the United States cooperate reciprocally. ${ }^{3}$ Hard-liners, however, are concerned that the reciprocal strategy could result in misleading North Korea into believing that the United States is spineless and, as a consequence, will give North Korea the chance to cheat on negotiated agreements or otherwise take advantage of cooperative moves by the United States. In short, the major concern of the reciprocal strategy is that North Korea would show inverse response behavior rather than reciprocal behavior.

While the theories of strategic response patterns reviewed thus far mainly focus on bilateral relations between states, one of the major interests of this study is the behavior of paired regional actors in response to a third outside power. Since the end of the Cold War, the main focus of international conflict and cooperation has shifted from superpower 
rivalries toward regional conflict and cooperation issues. Given the changed conflict landscape, a theory of outside power influence and triangular response patterns has been proposed as an alternative strategy to that of bilateral reciprocity. This theory is proposed to overcome the limits of bilateral theories and to demonstrate another means for eliciting cooperation in regional conflicts. It is suggested that a powerful external actor may play a role in overcoming the distrust inherent in the security dilemma through the use of enforcement, patronage, and norm setting (Kolodziej and Zartman 1996, 13; Goldstein et al. 2001, 598).

However, systematic analysis of the effects of different foreign policy approaches-bullying and reciprocity-in promoting or impeding cooperation in a regional and triangular setting is still lacking. Regarding triangular response in the context of regional conflict, Joshua Goldstein et al. (2001) and Goldstein and Jon Pevehouse (1997) report that there has not been enough research conducted on the influence of an external power in eliciting triangular response patterns among parties to conflict or rivalry. They specifically highlight the Serbia-Bosnia/international community and the Serbia-Kosovo/NATO relationship as instances where theories of bilateral interaction are not helpful in explaining these triangular patterns of interaction between actors, even though such patterns are more common in post-Cold War international relations. That is, while there has been significant theoretical development and empirical support for bilateral strategic response patterns between major powers utilizing both hard-line and reciprocity strategies, empirical support for regional triangular response patterns in the context of conflict or rivalry between states has been rare.

Because this study focuses on the progress or regression of peaceful relations between South and North Korea in response to US foreign policy, a theoretical framework that explains the outside power's influence and the triangular response of regional actors needs to be reviewed in addition to bilateral response theories.

In this study, I also attempt to elaborate the theory of outside power and triangular response patterns by developing a hypothesis on foreign policy coordination between two states-one regional actor and an outside power-toward another regional actor in a triangular relationship. Since the United States and South Korea are in an alliance relationship and each has its own foreign policy toward North Korea, the effect of US foreign policy on the level of peace in the Korean peninsula could be different depending on the level of policy cooperation between the United States and South Korea. This issue of foreign policy coordination has been relatively neglected in the established literature. 
First, the framework of external power influence and triangular response patterns can be applied to the situation in the Korean peninsula because the United States has been a dominant influence in the region since the end of the Cold War. Although other powerful states, such as Russia and China, might have had influence in the Korean peninsula as well, their influence has been significantly reduced during the post-Cold War era due to their priorities shifting from international expansion to domestic concerns such as economic development and ethnic conflicts. In particular, the dynamics of the relationship between North Korea and the United States have been central, particularly concerning North Korea's nuclear weapons program. Although China and other regional actors like Japan and Russia have also been concerned about North Korea's nuclear weapons program through the Six-Party Talks begun in 2003, the United States has taken the lead role in dealing with this issue. Contrary to the expectation that those regional powers would affect North Korean behavior, there has not been much evidence of their ability to influence North Korea. Rather, Grame Davies (2007) reports that regional powers such as China, Japan, and Russia did not have any impact on North Korean behavior toward South Korea.

US foreign policy toward the Korean peninsula has been considered critical both in eliciting cooperation and in escalating conflict between South and North Korea. For example, military tension escalated dramatically in the Korean peninsula during the first North Korean nuclear crisis with the United States in 1994, while more peaceful relations ensued following the first South and North Korean summit, which took place immediately after the US adoption of the "Perry initiative," an initiative that outlined a coexistence approach. Therefore, this study asks whether triangular responses to US actions by South and North Korea actually occur and, if so, whether triangular responses favor or impede the evolution of cooperation, especially progress toward peaceful relations in the Korean peninsula.

According to the theory of triangular response and outside power influence, triangular response occurs when a regional actor changes its behavior toward another regional actor in response to the behavior of an outside power. This response can be either inverse or reciprocal. An inverse response refers to a regional actor's increased level of hostility toward a regional rival after receiving cooperation from an outside power. The regional actor takes advantage of an outside power's cooperation to ratchet up hostility toward its regional rivals. An inverse response also includes the case of a regional actor taking a more cooperative stance 
toward its neighbor after receiving hostile signals from an outside power. When the regional actor adopts an inverse triangular response, the best strategy on the part of the external party for inducing cooperation is a hard-line approach, such as a policy of containment, which uses "tough" initiatives to elicit cooperation.

In contrast, a reciprocal triangular response refers to a pattern in which the regional actor increases cooperation toward a regional rival after receiving cooperative signals from an outside power, or becomes increasingly hostile toward its regional rival in response to an outside power's hostile action. In this case, the appropriate policy on the part of the external party for inducing regional cooperation is a soft-line approach, such as accommodation and unilateral cooperative initiatives (Goldstein et al. 2001, 599; Goldstein and Pevehouse 1997, 516). Regarding the situation in the Korean peninsula, the main concern is whether the US hard-line policy has adverse consequences for South Korea-North Korea relations. Although some believe that North Korea would try to cooperate with South Korea when the United States took a hard-line policy toward North Korea, critics of US policy such as Chungin Moon (2008) argue that the US hard-line policy would lead to North Korea's retaliation toward South Korea. Moon contends that US military actions against North Korea, whether a preemptive surgical strike on nuclear facilities or an all-out attack, would eventually increase the potential of major military conflict and catastrophe in the peninsula.

Another matter of interest is whether North Korea shows cooperative behaviors toward South Korea when the United States takes a soft-line policy toward North Korea. Some scholars argue that North Korea has responded positively to positive behaviors, especially when the proper incentives are given (Harrison 2003; Moon 2004; O'Hanlon and Mochizuki 2003). However, those arguments are mostly related to the bilateral behavior of North Korea toward the United States. There has not been enough research on the triangular behavior of North Korea toward South Korea in response to the soft-line US foreign policy. In short, the main interest is whether North Korea responds inversely or reciprocally toward South Korea in response to US foreign policy.

Synthesizing bilateral and triangular theories of strategic response patterns, I empirically examine which strategic response patterns are present in the volatile region of the Korean peninsula. Accordingly, I attempt to ascertain the effects of each US foreign policy strategy - hard-line versus reciprocal-in fostering cooperation between two states of that region. Specifically, I examine whether North Korea shows an inverse triangular 
or reciprocal triangular response toward the formation of peaceful relations with South Korea in response to US foreign policy initiatives, and how the effects of each of the strategies-hard-line and reciprocal on the part of the United States-compare in fostering the development of peaceful relations in the Korean peninsula.

Second, regarding the issue of policy coordination between South Korea and the United States, Scott Snyder (1999) indicates that close policy coordination between the two countries can block North Korea's attempt to exploit South Korea-US divisions or tactical differences. Therefore, it is plausible that if the United States and South Korea are strongly coordinated in their foreign policy orientation toward North Korea, the combined effect of those policies would be strong and eventually affect the level of peace in the peninsula. In a similar vein, it can be hypothesized if the United States and South Korea utilize divergent foreign policy strategies toward North Korea, each of their policies combined might have no significant effect on the level of peace in the Korean peninsula, due to the mixed effects of those policies on North Korea's behavior.

\section{Hypotheses and Data}

From the theories of strategic response patterns and cooperation among states, the following hypotheses are developed with regard to the level of peace in the Korean peninsula.

Hypothesis 1a: Hard-line US foreign policy facilitates peace in the Korean peninsula.

Hypothesis $1 b$ : Soft-line US foreign policy facilitates peace in the Korean peninsula.

Hypothesis 2: Divergent foreign policy approaches between the United States and South Korea have no significant effect on peace in the Korean peninsula.

Data compiled in the Integrated Data for Events Analysis (IDEA) are used to examine the strategic response patterns of four actors-the United States, North Korea, South Korea, and China. Event data such as World Events Interactions Survey (WEIS) and Conflict and Peace Data Bank (COPDAB) have been widely used for the analysis of state response patterns. Recently, the use of automated, machine-coded data systems, such as the Kansas Events Data System (KEDS), Textual Analysis 
by Augmented Replacement Instructions (TABARI), and IDEA, has increased due to the consistency and transparency of coding (Bond et al. 2003; Goldstein et al. 2001; Goldstein and Pevehouse 1997; Davies 2007). Among these automated, machine-coded data sources, I use IDEA because other sources do not contain data concerning state interactions in the Korean peninsula. The IDEA dataset is generated by using the Virtual Reader Associates (VRA) automated content analysis, a computerized reader program that parses Reuters Business Briefings, Factiva-World News, and Reuters. By parsing lead sentences, the VRA reader identifies actors and the actions taken between actors. They are coded by source, target, and type of event. In its coding, IDEA includes all types of events from WEIS. As a result, the IDEA data set contains over 10 million observations of daily state interactions in the international system.

In this study, I use a subset of these data, in which four states-the United States, North Korea, South Korea, and China-are actors and in which they are interacting with one another. While Davies's (2007) study shows no empirical support for the role of other actors-China, Japan, and Russia -in affecting either North Korea's behavior toward South Korea or South Korea's behavior toward North Korea, he does find that North Korea's relationship with China could affect US behavior toward North Korea. Moreover, China, as a member of the Four-Party Talks during 1997-1998 and the chair of the Six-Party Talks since 2003, has been considered an actor that balances the United States in dealing with North Korea's nuclear program and missile issues. In particular, China, as an ally that provides food and energy assistance to North Korea, has been expected to exert a certain degree of diplomatic influence on North Korea. Therefore, I include China as a control variable in this study. Including China also makes it possible to see if there is a similar triangular relationship involving China's influence on relations between North and South Korea. However, I exclude Japan and Russia from the model because, unlike China, their role in affecting the relationship between South and North Korea has not been regarded as significant (Davies 2007), even though they are members of the Six-Party Talks. Including irrelevant variables results in a higher variance for estimators and thus leads to a less efficient estimator problem. The time period covered, 1990-2004 (because of data availability), includes the period of the first nuclear crisis and the first two full years of the second nuclear crisis.

Since IDEA categorization is not consistently ordered from "conflict" to "cooperation," each type of event is converted into Goldstein's weighted "net cooperation scale," which ranges from -10 (most hostile) 
to 8.3 (most cooperative). The converted data are then aggregated from daily to monthly intervals in which the monthly score of hostile behavior is subtracted from the monthly score of cooperative behaviors. For example, an event such as "accusation" is converted to -2.2 , which indicates hostile behavior. In a similar vein, "agree or accept" is converted to 3.0, showing that it is a cooperative behavior. The aggregated score of these two events, if there are only two events in a given month, would be 0.8. A total of 28,891 events are aggregated over a given period to generate these scores. ${ }^{4}$

To decide the appropriate level of temporal aggregation, the characteristics of events need to be considered. In the case of events that move relatively quickly, such as the Bosnian conflict (Goldstein and Pevehouse 1997), daily or weekly aggregation would be appropriate. For a relatively long-term conflict that does not move rapidly, such as superpower rivalry during the Cold War era, monthly (Goldstein and Freeman 1991) or even longer temporal aggregation (such as annual or quarterly) would provide a better fit. This study regards the monthly temporal aggregation as the most appropriate because the North Korea-South KoreaUnited States relationship is a relatively long-term interaction. Annual or quarterly aggregation could dilute the dynamics of state interactions. Also, annual observations over fifteen years would be too few observations. Therefore, this study presumes that patterns of states' response are most readily apparent with monthly aggregation of events. Accordingly, the unit of analysis is event-month. After the aggregation, 178 observations remain, covering the period July 1990-September 2004.

\section{Analysis}

To test the hypotheses, I use statistical analysis by employing a VAR time series model. A VAR model is a system of several independent equations, where each dependent variable is regressed on its past values and the past values of the other variables in the system (Brandt and Williams 2007; Sims 1980). The VAR model is useful for the analysis of international interactions because it allows for the analysis of several actors' behavior toward one another. In the context of this research, it allows for the analysis of not only bilateral behavior between North Korea and the United States, but also triangular behavior among North Korea, South Korea, and the United States. In addition, multiple hypotheses can be tested and compared by using the VAR model. The VAR model in this study contains ten equations and can be expressed as follows, using matrix notation. 
$Y=B X+e$,

with

$Y=(P K t, N K-S K t, N K-U S t, N K-C N t, S K-N K t, S K-U S t, S K-C N t$, $U S-N K t, U S-S K t, U S-C N t, C N-N K t, C N-S K t, C N-U S t)$

$B=\left(\begin{array}{ccc}a_{110} & \cdots & a_{1 m n} \\ \vdots & \ddots & \vdots \\ a_{p 10} & \cdots & a_{p m n}\end{array}\right)$

$X=(1, P K t-i, N K-S K t-i, N K-U S t-i, N K-C N t-i, S K-N K t-i, S K-U S t-i$, $S K-C N t-i, U S-N K t-i, U S-S K t-i, U S-C N t-i, C N-N K t-i, C N-S K t-i$, $C N-U S t-i, N K R t, S K R t, U S R t$, USSKPD $t)$

$e=(e 1, e 2, e 3, e 4, e 5, e 6, e 7, e 8, e 9, e 10)$

where, $P K=$ the level of overall peace in Korean peninsula ${ }^{5}$ $N K-S K=$ North Korea's level of net cooperation toward South Korea $N K-U S=$ North Korea's level of net cooperation toward the United States

$N K-C N=$ North Korea's level of net cooperation toward China

$S K-N K=$ South Korea's level of net cooperation toward North Korea

$S K-U S=$ South Korea's level of net cooperation toward the United States

$S K-C N=$ South Korea's level of net cooperation toward China

$U S-N K=$ US level of net cooperation toward North Korea

$U S-S K=$ US level of net cooperation toward South Korea

$U S-C N=$ US level of net cooperation toward China

$C N-N K=$ China's level of net cooperation toward North Korea

$C N-S K=$ China's level of net cooperation toward South Korea

$C N-U S=$ China's level of net cooperation toward the United States

The $e$ 's are error terms.

These variables are treated as endogenous because their behavior toward one another is usually affected by others' behavior. The summations are for $i=1, \ldots L$, where $L$ is the number of lags of the right-handside variables in each equation. For appropriate lag lengths, an Akaike's information criterion (AIC) test, a Bayesian information criterion (BIC) test, and the likelihood ratio test for lag length are used. Two lags of variables are included in the model, based on the results of diagnostic statistics for specification of the lag length. Therefore, it is assumed that the 
behavior of states over the previous two months affects the reactions of each related state in the model. ${ }^{6}$

The three other variables - changes of government in South Korea $(S K R)$, North Korea $(N K R)$, and the United States (USR)-are exogenous because it is unlikely that changes of government in those states are affected by the interactive behavior with the other states. However, it is likely that changes of government in one state affect that state's behavior toward other states. In the two democracies-South Korea and the United States-changes of government might highlight the different foreign policy orientations between parties on the right and those on the left. The general perception is that leftist parties usually prefer soft-line policies (e.g., the Clinton administration's negotiated settlement and engagement policy or Kim Dae-jung's sunshine policy), while right-wing parties favor hard-line policies toward North Korea (the Bush administration's hostile policy that depicted North Korea as a rogue state). In North Korea, the coefficient on this variable will only indicate the difference between father and son. However, it is still interesting whether different North Korean leaders show different foreign policy orientations. These change of government variables are treated as dummy variables and are coded 0 for the following: Kim Il Sung's government in North Korea, which lasted until 1994; conservative administrations in South Korea (the Democratic-Liberal Party, New Korea Party, and Grand National Party); and Republican administrations in the United States. Other governments, such as Kim Jung Il's government in North Korea, the New Millennium Democratic Party's administration in South Korea, and Democratic administrations in the United States are coded 1.

The variable USSKPD is also treated as a dummy and as an exogenous variable. It represents whether there is disparity between the foreign policy approaches of the United States and South Korea toward North Korea in terms of cooperation and conflict, measured using Goldstein's scale. When Goldstein's "net cooperation score" is positive or equal to 0 , it is regarded as "cooperation." When Goldstein's net cooperation score is negative, it is considered "conflict." The variable is coded 1 when the United States and South Korea have different approaches toward a third state-North Korea-in terms of cooperation and conflict in a given month, and 0 otherwise. ${ }^{7}$

The dependent variable of interest in the VAR model is the level of overall peace in the Korean peninsula, which is represented by the variable $P K$. This is measured by what both South and North Korea do toward each other in the IDEA dataset. ${ }^{8}$ This measure is different from the South-North or North-South dyads' cooperation scores because it does not reflect the direction of one party's cooperation toward the counterpart. Rather, this 
measure indicates how peaceful the relationship is between the two Koreas as a whole. ${ }^{9}$ The independent variables of main interest are US foreign policy in the Korean peninsula-in particular, its policy toward North Korea, including diplomatic recognition, promises of economic or humanitarian support, acceptance of invitations and proposals, displays of enmity or hospitality, threats of military action or promises of nonmilitary action, economic sanctions or economic assistance, and the level of military deployment and military operations in the Korean peninsula. For US foreign policy toward South Korea, whether there is policy coordination toward North Korea or not is the main interest, because South Korea and the United States are in an alliance relationship.

First, the face validity of the data as coded and scaled is examined by generating time series graphs of the main interactions between states so that the time series can be visually inspected. These are depicted in Figures 1 and 2 for the main variables of interest.

Figures 1 and 2 display net cooperation scores from 1990 to 2004, with positive scores reflecting varying degrees of cooperation and negative scores indicating conflict. The spikes correspond to major political events, such as the capture of a North Korean submarine in the East Sea

\section{Figure 1 Net Cooperation Between Korean Dyad and Peace in the Korean Peninsula}

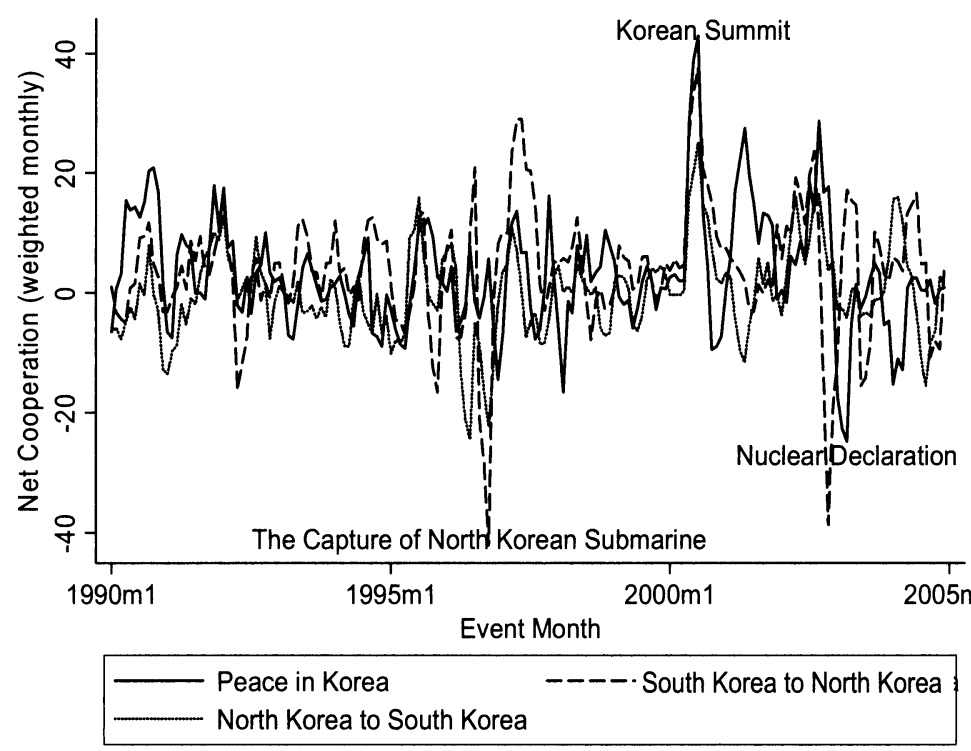

Note: This graph is smoothed using a three-month moving average to make it easy to read. 
Figure 2 US Net Cooperation to North Korea and South Korea

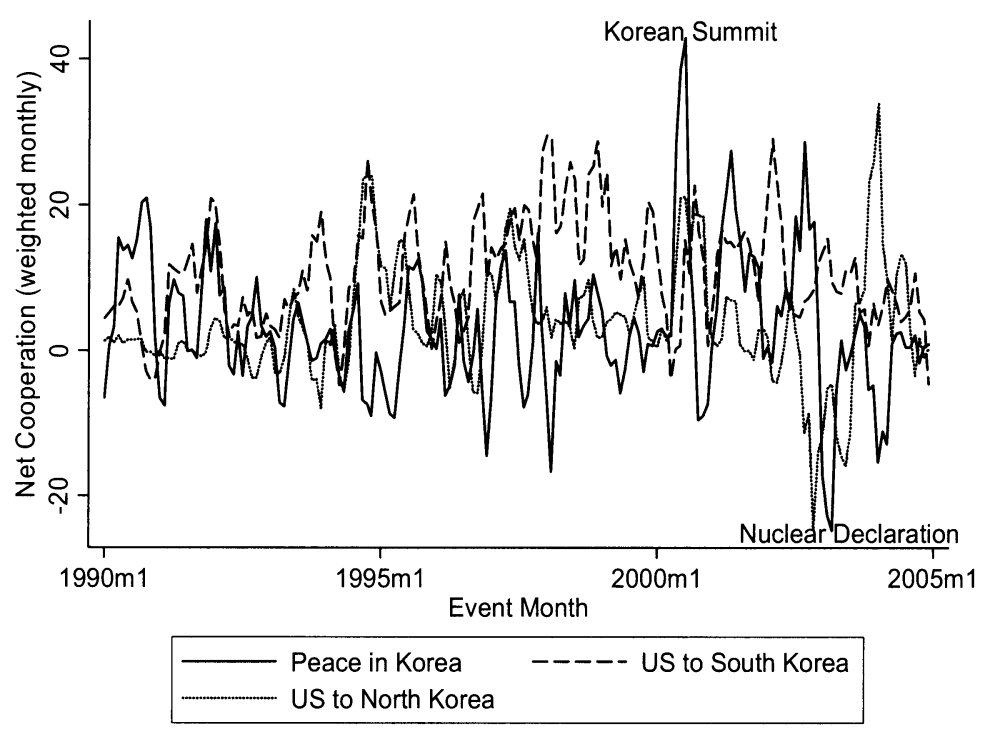

Note: This graph is smoothed using a three-month moving average to make it easy to read.

of South Korea, the first Korean summit between South Korean president Kim Dae-jung and North Korean leader Kim Jung Il, and the North Korean declaration of its possession of nuclear weapons. Other spikes include events such as North Korean's withdrawal from the Nuclear NonproliferationTreaty (NPT), and meetings between South and North Korean separated family members. In Figure 2, US behavior toward North Korea appears to co-vary with "peace in Korea." This is confirmed later in this study with statistically significant evidence $(<.05)$ that US behavior has an effect on peace in Korea by having positive correlation with North Korean behavior toward South Korea, which in turn affects "peace in Korea." 10

For the estimation of the VAR model, the Granger causality test and impulse response analysis are used. First, the coefficients of each lagged variable are examined. Although the significance of each lagged term is considered less important than the combined significance of the lagged coefficients in the VAR analysis, examining the significance of each lagged term can still be useful for showing which lagged terms of variables have effects on the dependent variables of each equation. It is plausible that one actor's behavior might affect that of another actor even after a certain period of time has passed. 
Second, to examine the behavior of the system and all the coefficients that describe the dynamics of the variables, a Granger causality test is used. The Granger causality test estimates whether lagged independent variables affect unlagged dependent variables by using F-tests in the VAR model. Each F-test shows the significance of Granger causality by assessing the joint significance of one independent variable with all its lags on the dependent variable.

Third, to assess the direction of these relationships, impulse response analysis is used. By conducting a simulation of the response of an equation ("simulated shocks to the model"), the nature of responses in the system can be assessed as to whether it is reciprocal, inverse, or ambiguous. Therefore, impulse response plots are generated in order to see how the system of equations reacts to a positive, one standard deviation shock to each variable. The direction of the response is assessed by the sum of the point estimates of responses to the simulated shock. A positive sum indicates a reciprocal relationship in which an actor responds with cooperation against an opponent's cooperation and hostility in response to hostility. A negative sum shows an inverse response, which denotes a hostile response against the opponent's cooperation, and vice versa. A sum that is close to zero and includes both positive and negative terms is considered an ambiguous relationship.

In the case of the exogenous variables-government change in any one of the states, and foreign policy coordination between South Korea and the United States - the estimated coefficients of those variables from VAR analysis describe the statistical significance and the direction of variables. That is, a positive coefficient on the US partisan variable when the dependent variable is US behavior toward North Korea, for example, means that the Democratic administrations are more cooperative toward North Korea than Republican administrations.

\section{Findings}

An examination of the results of the initial VAR model analysis reveals a reasonably good overall fit of the model, with $R$-squared values that range from .34 to $.13 .^{11}$

Table 1 presents the result of the VAR analysis. It shows how each lagged term of the independent variables affects the dependent variable of each equation. For the equation Peace in Korea, which indicates overall peace in the Korean peninsula, the VAR results show that peace in Korea is most directly affected by North Korea's behavior toward South Korea and the United States. The second lagged term of North Korea's 
Table 1 The Effect of Each Lagged Term of State Interaction in the VAR Analysis

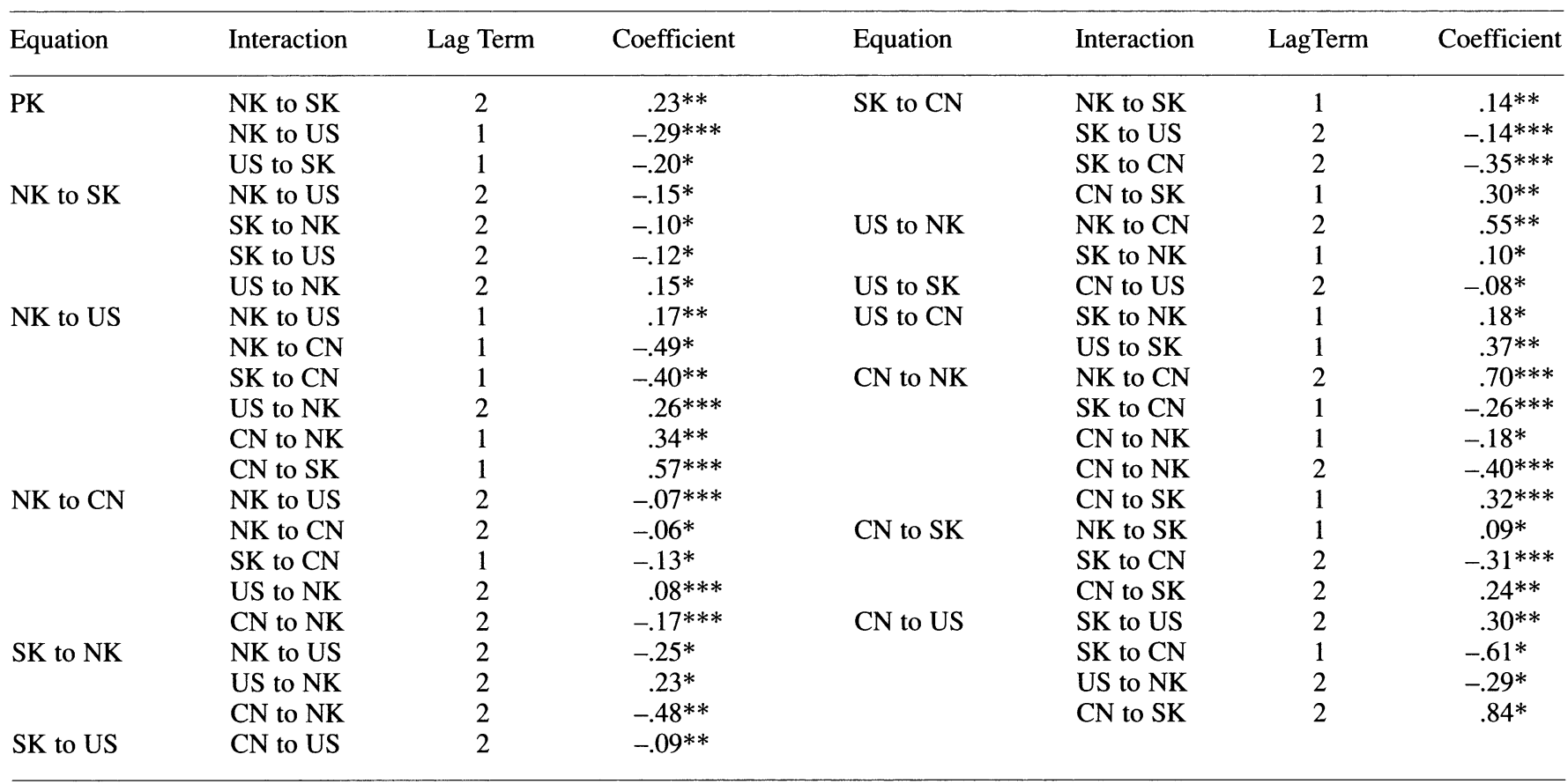

Notes: $\mathrm{PK}=$ Peace in Korea, $\mathrm{SK}=$ South Korea, $\mathrm{NK}=$ North Korea, $\mathrm{CN}=$ China, US $=$ United States. $* * * p<.01, * * p<.05, * p<.1$ 
behavior toward South Korea-North Korea's behavior toward South Korea two months prior to the event pertaining to the dependent variable-is statistically significant at the .05 percent level. The first lagged term of North Korea's behavior toward the United States-North Korea's behavior toward the United States one month prior to the event pertaining to the dependent variable-is also statistically significant at the .01 percent level. This result shows that North Korea's behavior toward either South Korea or the United States is the most critical of all interactions among these three states for the promotion of peace in the Korean peninsula. The next logical question is which interaction affects North Korea's behavior toward South Korea and the United States?

The results in Table 1 indicate that North Korea's behavior toward South Korea is affected by the United States-to-North Korea interaction, and North Korea's behavior toward the United States is affected by the United States-to-North Korea interaction. In the North Korea-to-South Korea equation, the second lagged term of the United States-to-North Korea interaction is significant at the .05 level. In the North Korea-toUnited States equation, the second lagged term of United States-to-North Korea is significant at the .01 level. Thus, US behavior toward North Korea is critical for both North Korea's behavior toward South Korea and North Korea's behavior toward the United States. In other words, US behavior toward North Korea indirectly affects peace in the Korean peninsula by affecting North Korea's behavior, which in turn is critical for peace in the Korean peninsula. This result demonstrates a triangular relationship among the United States, North Korea, and South Korea. The triangular response pattern can be linked as the United States $\rightarrow$ North Korea $\rightarrow$ South Korea. In sum, US foreign policy affects peace in the Korean peninsula indirectly by affecting North Korea's behavior, which in turn is one of the most significant determinants of peace in the peninsula.

Table 2 presents the Granger causality test and impulse response analysis results for all statistically significant state interactions. It is important to get at endogeneity of these relationships because a state's behaviors are often affected by other states' behaviors toward the state. For example, some of the big issues are whether North Korea's behavior affects US behavior or vice versa, and whether US hard-line response is a result of North Korean behavior or vice versa.

For the peace in the Korean peninsula equation, none of the independent variables are significant, contrary to expectations. In the previous analysis where each lagged term was considered separately, two interactions-North Korea-to-South Korea (second lag term) and North Korea-to-the United States (first lag term) - were significant. However, 
Table 2 The Effect of US Foreign Policy on Peace in the Korean Peninsula (Granger Causality Test and Impulse Response Results)

\begin{tabular}{|c|c|c|c|c|}
\hline Dependent Variable & Independent Variable & $C h i^{2}$ & $P>$ & Direction \\
\hline North Korea to & North Korea to US & 5.08 & $.079 *$ & \\
\hline \multirow[t]{2}{*}{ South Korea } & South Korea to North Korea & 4.75 & $.093 *$ & \\
\hline & US to North Korea & 4.17 & .124 & + \\
\hline \multirow{4}{*}{ North Korea to US } & South Korea to China & 7.80 & $.020 * *$ & - \\
\hline & US to North Korea & 11.57 & $.003 * * *$ & + \\
\hline & China to North Korea & 4.59 & .101 & + \\
\hline & China to South Korea & 8.22 & $.016^{* *}$ & + \\
\hline \multirow[t]{4}{*}{ North Korea to China } & North Korea to US & 4.46 & $.107 * *$ & \\
\hline & South Korea to China & 3.97 & .137 & - \\
\hline & US to North Korea & 6.48 & $.039 * *$ & + \\
\hline & China to North Korea & 8.29 & $.016^{* *}$ & - \\
\hline South Korea to & North Korea to US & 3.72 & .156 & - \\
\hline North Korea & US to North Korea & 3.93 & .140 & + \\
\hline \multirow[t]{2}{*}{ South Korea to US } & North Korea to South Korea & 4.22 & .122 & - \\
\hline & China to US & 3.91 & .142 & - \\
\hline \multirow{3}{*}{ South Korea to China } & North Korea to South Korea & 5.35 & .069 & + \\
\hline & South Korea to US & 6.51 & .039 & - \\
\hline & China to South Korea & 6.39 & .041 & + \\
\hline US to North Korea & North Korea to China & 4.82 & $.090 *$ & + \\
\hline US to China & US to South Korea & 5.46 & $.065^{*}$ & + \\
\hline \multirow[t]{3}{*}{ China to North Korea } & North Korea to China & 22.44 & $.000 * *$ & + \\
\hline & South Korea to China & 6.35 & $.042 * *$ & - \\
\hline & China to South Korea & 6.04 & $.049 * *$ & + \\
\hline China to South Korea & South Korea to China & 9.69 & $.008 * * *$ & - \\
\hline China to US & South Korea to US & 5.55 & $.062 * *$ & \\
\hline
\end{tabular}

Note: $* * * p<.01, * * p<.05, * p<.1$

the Granger causality test, which assesses the joint significance of all lags on a dependent variable, shows none of the independent variables to be statistically significant.

Despite the unexpected results observed from the Granger causality test for the peace in Korea equation, the effects of North Korea's behavior toward South Korea on overall peace in Korea are relatively more significant than the other state-to-state interactions $(p<.11)$, and the results of other equations confirm the findings of the previous analysis. The previous analysis indicates that the most significant factor affecting peace in the Korean peninsula is North Korea's behavior toward South Korea, and North Korea's behavior is affected by US behavior toward North Korea. Similarly, the Granger causality test results indicate that North Korea's behavior toward South Korea is affected by North Korea's 
behavior toward the United States, which is itself affected by US behavior toward North Korea. Therefore, both the VAR with divided lagged terms and the Granger causality tests show that US foreign policy affects peace in the Korean peninsula indirectly by affecting North Korean behavior toward South Korea, indicating the presence of a triangular response pattern among the United States, North Korea, and South Korea.

Regarding the bilateral relationship between North Korea and the United States, the Granger causality test results indicate that North Korean behavior toward the United States is strongly affected by US behavior toward North Korea $(p>.003)$. These results support the qualitative findings of Leon Sigal (1998) and V. D. Cha and D. C. Kang (2003), and disconfirm Davies's (2007) finding, the latter of which uses a shorter time period (1990-2000) than that of this study (1990-2004). However, US behavior toward North Korea is not affected by North Korea's behavior toward the United States, according to the Granger causality test results. Rather, US behavior toward North Korea is affected by government changes in the United States. ${ }^{12}$

Regarding the direction of the specific relationship-inverse or reciprocal - between states, impulse response plots indicate that a positive shock in US behavior toward North Korea increases the reciprocal behavior of North Korea toward South Korea. This result shows that North Korea responds reciprocally toward a third party - South Korea - against US behavior toward North Korea. More cooperative US behavior toward North Korea elicits more cooperative North Korean behavior toward South Korea. Likewise, hostile US behavior toward North Korea is more likely to lead to hostile North Korean behavior toward South Korea. This suggests that a reciprocal pattern of triangularity exists among the United States, North Korea, and South Korea. This finding confirms Hypothesis $1 b$-that cooperative US foreign policy for the Korean peninsula facilitates peace in the Korean peninsula-while rejecting Hypothesis la of hard-line foreign policy and peace linkage. For the bilateral relationship between North Korea and the United States, a strong reciprocal response pattern regarding North Korea's behavior toward the United States exists as well. That is, North Korea responds with hostility toward the United States when the United States uses hard-line policies toward North Korea. In a similar vein, North Korea's cooperative response toward the United States is a result of US cooperative behavior toward North Korea. This result supports Moon's argument (2008) that North Korea has responded positively to positive behavior, and vice versa.

For the policy coordination hypothesis between South Korea and the United States, it appears that when South Korea and the United States 
employ different strategies in terms of cooperation or hostility toward North Korea, the respective policy of these states has no statistically significant effect on peace in the Korean peninsula. However, an interesting finding is that the results tell a different story when triangular relationships are considered. According to the results, there is a triangular effect of a policy disparity on peace in the Korean peninsula. The policy coordination variable is statistically significant at the 0.05 level on US behavior toward North Korea, and the direction is negative. This result shows that a larger policy disparity between South Korea and the United States is associated with more hostile US foreign policy toward North Korea. Given that US behavior toward North Korea affects North Korea's behavior toward South Korea reciprocally, which is directly related to the level of peace in the Korean peninsula, this result suggests that there is also a triangular relationship that affects peace in the Korean peninsula. This link can be shown as follows: "The policy disparity between South Korea and the United States $\rightarrow$ US hostile foreign policy toward North Korea $\rightarrow$ North Korea's hostile behavior toward South Korea $\rightarrow$ degrading level of peace in the Korean peninsula." Therefore, Hypothesis 2-that different foreign policy approaches between the United States and South Korea have no significant effect on peace in the Korean peninsula-is disconfirmed. Rather, the finding shows that a different foreign policy approach could imperil peace in the Korean peninsula. One thing to consider regarding this result is that a disparity could arise either because the United States is more hostile or less hostile to North Korea. Here, it looks as if the result reflects situations where the United States takes hard-line approaches while South Korea is cooperative toward North Korea. Therefore, this result suggests that US hardline policies that are not coordinated with South Korean policies toward North Korea could lower the level of peace in the peninsula.

With regard to leadership in North Korea and partisanship in the democracies as control variables, government changes in South Korea, North Korea, and the United States have no statistically significant effect on peace in Korea. But government changes in South Korea affect North Korea's behavior toward the United States. The transition of power in South Korea from the conservative New Korea Party to the liberal Democratic Party (Uri Party from 2003 to 2007) in 1998 does not have a statistically significant effect on its own policy toward North Korea. However, the change of government in South Korea has had a statistically significant and negative effect on North Korea's behavior toward the United States. This finding suggests that North Korea's behavior is more hostile toward the United States when the Democratic Party of 
South Korea is in power, a government that takes a more proengagement stance. Another interesting finding is that US government changes affect US behavior toward North Korea. It is statistically significant at the .05 level, and it shows a positive direction. This result suggests that US Democratic administrations are more cooperative toward North Korea than Republican administrations. However, contrary to the case of government changes in South Korea, US government changes do not affect North Korea's behavior toward the United States.

The results also confirm the "Chinese influence on North Korea" that has been widely acknowledged by many analysts regarding the North Korean nuclear issue. Chinese behavior toward North Korea affects North Korea's behavior toward the United States when the lag term is one month (the first lag term). The direction is positive, and it is statistically significant at the .05 level. This suggests the existence of a reciprocal triangular relationship between China, North Korea, and the United States. In other words, more cooperative behavior by China toward North Korea leads to more cooperative behavior by North Korea toward the United States. Likewise, less cooperative behavior by China toward North Korea has a negative effect on North Korea's cooperative behavior toward the United States. As is widely recognized, China influences North Korea. Regarding US influence on China, the results show that US behavior does not have any significant effect on China's behavior toward North Korea. Rather, according to the Granger causality test, China's behavior toward North Korea is significantly affected by bilateral relations with North Korea. The impulse response results show that a positive shock in South Korea's behavior toward China increases the inverse behavior toward North Korea. That is, South Korea's behavior toward China affects China's behavior toward North Korea. However, the direction in this relationship is negative. This shows that more cooperation by South Korea toward China leads to less cooperation by China toward North Korea. This result suggests that South Korea's diplomacy toward China works because South Korea's national interests are often opposite from those of North Korea on many issues, such as North Korea's nuclear weapons development or ballistic missile tests, and South Korea's cooperation toward China has an inverse effect on North Korea.

In sum, US foreign policy has an effect on peace in the Korean peninsula by affecting North Korea's behavior toward South Korea, which in turn determines the level of peace in the Korean peninsula. Therefore, a triangular response pattern exists among the United States, North Korea, and South Korea, and this triangular relationship appears to be reciprocal, which signifies the behavior pattern that responds with 
cooperation against an opponent's cooperation, and hostility against hostility. Thus, it confirms the expectation of Hypothesis $1 b$ that cooperative US foreign policy facilitates peace in the Korean peninsula. Accordingly, Hypothesis $1 a$, which links hard-line foreign policy and peace, can be rejected. However, US behavior toward South Korea does not have a significant effect on South Korea's behavior toward North Korea. So, reciprocal triangularity takes place only in one direction, which is US $\rightarrow$ North Korea $\rightarrow$ South Korea.

Hypothesis 2-that the presence of divergent US and South Korean policies toward North Korea has no significant effect on peace in the Korean peninsula-is disconfirmed. Rather, there is an interesting finding that policy disparity between South Korea and the United States affects US behavior toward North Korea inversely, and thus affects peace in the Korean peninsula indirectly. Changes of government in South Korea, North Korea, and the United States have no significant effect on peace in Korea. But changes of government in South Korea affect North Korea's behavior toward the United States. When the Democratic Party (Uri Party from 2003 to 2007 ) of South Korea is in power, North Korea has shown more hostile behavior toward the United States. The United States tends to be more cooperative toward North Korea when the United States has a Democratic rather than a Republican administration.

The findings also show that China has influence on North Korea's behavior toward the United States. However, US influence on China concerning China's behavior toward North Korea is not significant, while South Korea has exerted significant influence on China on the same matter. The summary of all these relationships is presented in Table 3.

\section{Conclusion}

This study provides a comprehensive picture of how US foreign policy toward states in the Korean peninsula affects peace there. The findings support the theory of reciprocity, as opposed to a hard-line approach, as the best means for achieving peaceful relations. Both bilateral and triangular reciprocity have occurred among the three states for the time period examined in this study. The relationship between North Korea and the United States shows bilateral reciprocity. Similarly, the triangular relationship among the United States, North Korea, and South Korea shows triangular reciprocity.

A particularly noteworthy finding is that reciprocity occurs even when there is power asymmetry between states, which contradicts the 
Table 3 The Effect of US Foreign Policy on Peace in the Korean Peninsula (summary)

\begin{tabular}{|c|c|c|c|c|}
\hline Equation & $\begin{array}{l}\text { Independent Variable/ } \\
\text { Control Variable }\end{array}$ & $\begin{array}{l}\text { Lag Term/ } \\
\text { Granger }\end{array}$ & $\begin{array}{c}\text { Coefficient/ } \\
\text { Chi }^{2}\end{array}$ & $\begin{array}{l}\text { Direction } \\
\text { (IRF) }\end{array}$ \\
\hline \multirow[t]{4}{*}{ Peace in Korea } & North Korea to South Korea & 2 & $.23^{*}$ & \\
\hline & North Korea to US & 1 & $-.30 * *$ & \\
\hline & US to South Korea & 1 & $-.19 *$ & \\
\hline & North Korea to US & Granger & $8.26 * *$ & - \\
\hline North Korea to & US to North Korea & 2 & $.16^{* *}$ & \\
\hline \multirow[t]{3}{*}{ South Korea } & South Korea to North Korea & 2 & $-.10 *$ & \\
\hline & South Korea to North Korea & Granger & $4.75 *$ & \\
\hline & North Korea to US & Granger & $5.08 *$ & \\
\hline \multirow[t]{8}{*}{ North Korea to US } & US to North Korea & 2 & $.26^{* * *}$ & \\
\hline & US to North Korea & Granger & $11.57 * * *$ & + \\
\hline & North Korea to China & 1 & $-.49 *$ & \\
\hline & South Korea to China & 1 & $-.40 * *$ & \\
\hline & South Korea to China & Granger & $7.80 * * *$ & - \\
\hline & China to North Korea & 1 & $.34 * *$ & \\
\hline & China to South Korea & 1 & $.57 * * *$ & \\
\hline & South Korea Government & & $-4.98 * *$ & \\
\hline \multirow{2}{*}{$\begin{array}{l}\text { South Korea to } \\
\text { North Korea }\end{array}$} & North Korea to US & 2 & $-.25^{*}$ & \\
\hline & US to North Korea & 2 & $.23 *$ & \\
\hline \multirow[t]{6}{*}{ US to North Korea } & North Korea to China & 2 & $.034 * *$ & \\
\hline & North Korea to China & Granger & $4.82 *$ & + \\
\hline & South Korea to North Korea & 1 & $.097 *$ & \\
\hline & North Korea Government & & $5.62 * *$ & \\
\hline & US Government & & $4.38 * *$ & \\
\hline & Policy Disparity & & $-3.40 *$ & \\
\hline \multirow{5}{*}{$\begin{array}{l}\text { China to } \\
\text { North Korea }\end{array}$} & North Korea to China & 2 & $.70 * * *$ & \\
\hline & North Korea to China & Granger & $22.44 * *$ & + \\
\hline & South Korea to China & 1 & $-.26 * *$ & \\
\hline & South Korea to China & Granger & $6.35 * *$ & - \\
\hline & North Korea Government & & $3.51 * *$ & \\
\hline
\end{tabular}

Notes: Granger $=$ Granger causality test result; IRF $=$ Impulse Response Function result. $* * * p<$ $.01, * * p<.05, * p<.1$

expectations of those arguing for the limits of using reciprocal strategies (Rubin and Brown 1975; Zartman 1997; Goldstein et al. 2001). The results of this study indicate that reciprocity can indeed occur between a superpower (the United States) and a small country (North Korea). This finding might be explained by other factors, such as the potential power of North Korea's nuclear weapons program and ballistic missiles. One could also explain this sort of reciprocity between a small state and a 
superpower by pointing to the US alliance relationship with South Korea. That is, North Korea may exhibit reciprocal behavior toward the United States out of consideration that North Korea could retaliate against South Korea, which is within the range of North Korea's artillery and missiles. Still, however, the findings of this study show that military power symmetry might not always be a critical condition for bilateral reciprocity. Regarding the specific relationship between North Korea and the United States, this study supports the findings of qualitative research concerning the effects of bilateral reciprocity between the United States and North Korea and its effects on the promotion of peace in the Korean peninsula (Sigal 1998; Cha and Kang 2003). That is, engaging North Korea appears to elicit more cooperative behavior than challenging it.

This study also supports the theory linking outside power influence and corresponding triangular response patterns. Specifically, it shows that there is a triangular response pattern in which US foreign policy in the Korean peninsula has a significant effect on peace in the region by affecting North Korea's behavior toward South Korea. The direction of the response is reciprocal. These results suggest that more cooperative US foreign policy toward North Korea appears to elicit more cooperative behavior by North Korea toward South Korea, and this-North Korea's cooperative behavior toward South Korea-eventually promotes peace in the peninsula. Similarly, more hostile US foreign policy toward North Korea is more likely to elicit more hostile behavior by North Korea toward South Korea, and this imperils peace in the peninsula. Therefore, while the existing literature does not offer sufficient empirical support for the theory linking outside power influence and triangular response patterns, this study provides a confirmation of this theory.

Pertaining to the specific relationship among the United States, North Korea, and South Korea, this study disconfirms recent quantitative research covering a shorter time period (1990-2000) in which Davies (2007) claims that North Korea's behavior toward South Korea is unaffected by other states.

In spite of these results showing North Korea's tendency for reciprocal behavior, there remains widespread suspicion about North Korea's intentions and the trustworthiness to commit to a reciprocal relationship. The perception is based on several cases in which North Korea is deemed to have cheated on negotiated agreements and promises. Those cases include breaking the Geneva agreement of 1994 and developing the uranium enrichment program for nuclear weapons, provoking military clashes in the Yellow Sea in 2002, not following through on the promise 
of family reunions after the first summit between South and North Korea in 2001, and testing long-range missiles and nuclear weapons in 2006 after the Six-Party Talks September 19, 2005, joint statement (known as the 9-19 statement), which declared the discontinuation of North Korea's nuclear program in exchange for energy assistance from the United States and other countries.

There can be two possible explanations for the suspicion about North Korea's trustworthiness for reciprocal relationships. First, contrary to the public perception of North Korea's constant cheating that has been widely highlighted in the mass media, the evidence regarding which side is ultimately responsible for breaking agreements and promises is highly contested. Selig Harrison (2005) points out, for instance, that the United States misrepresented and distorted data when it accused North Korea of secretly developing its uranium-based nuclear program in 2002. Following these accusations, the United States suspended the oil shipments that it had been providing to North Korea under the 1994 Geneva agreement. This led North Korea to react reciprocally and resume the reprocessing of plutonium. O'Hanlon and Mochizuki (2003) argue that US unwillingness to address North Korea's broader security concern through such mechanism as a peace treaty and conventional force reduction might have led North Korea to think it needed a nuclear deterrent against a potential attack from either the United States or South Korea. They also indicate that the Bush administration's hostile attitude toward North Korea (declaring it a member of the "axis of evil"), US emphasis on preemptive action, and the US invasion of Iraq might have led North Korea to believe it could be the next target. That is, although there might not have been direct and tangible interactions between North Korea and the United States, these contextual factors might have induced North Korea's reciprocal action, which included breaking off the Geneva agreement and developing the secret uranium enrichment program. ${ }^{13}$

Second, despite some possible cases of North Korea's breaching agreements and promises, the conclusions of this study might be valid because the findings reflect the general pattern of North Korea's behavior. The finding that North Korea has shown a pattern of reciprocal behavior matches the findings from other qualitative studies as well (Cha and Kang 2003; Snyder 1999).

In conclusion, US foreign policy affects peace in the Korean peninsula by affecting North Korea's behavior toward South Korea, which most significantly affects peace in the peninsula relative to the effects of other state interactive behavior. The triangular relationship among the United 
States, North Korea, and South Korea shows a reciprocal behavior pattern.

Regarding practical foreign policy implications, the findings of this study suggest the following. First, they suggest that cooperative and reciprocal foreign policy on the part of the United States toward North Korea is better than hard-line policies for promoting peace in the Korean peninsula. As the analysis shows, it is likely that North Korea would react with more hostile behavior toward South Korea and the United States if the United States were to maintain a hostile policy toward North Korea. North Korea's rejection of the opportunity to participate in a conversation with the United States (February 2002), and the subsequent continuation of its nuclear weapons development program (admitted by North Korea in October 2002) following the Bush administration's inclusion of North Korea in the list of states deemed members of the "axis of evil" (January 2002) are examples of North Korea's behavioral response pattern in light of threats made on the part of the United States.

Second, the findings suggest that the diplomatic capacity of South Korea in coordinating the policy toward North Korea with the United States is important for promoting peace in the Korean peninsula. According to the findings presented in this study, the larger policy disparity between South Korea and the United States is associated with more hostile US behavior toward North Korea, which in turn could lead to more hostile North Korean behavior toward South Korea. This situation might come from the case where the United States takes a hawkish position while South Korea maintains a dovish stance. In other words, the United States might act aggressively toward North Korea, even taking the risk of jeopardizing peace in the peninsula when there is not sufficient diplomatic effort to maintain some degree of balance and cooperation between South Korea and the United States. This suggests that South Korea should exert some level of diplomatic effort to mitigate policy disparity, especially when its policy position is completely different from that of the United States, in order to maintain peace in the peninsula. A balanced approach that considers both peace in the Korean peninsula and the solid alliance relationship with the United States might need to be pursued.

Jong-Han Yoon is a lecturer in the Graduate School of Policy Studies and the School of Public Administration at Korea University. He earned his $\mathrm{PhD}$ in political science from the University of North Texas. His research interests include East Asian politics, peace studies, environmental politics, and comparative public policy. 


\section{Appendix}

The Result of Unit Roots Test

\begin{tabular}{lcccccccc}
\hline Lags & PK & NK-SK & NK-US & NK-CN & SK-NK & SK-US & SK-CN \\
\hline 1 & -8.04 & -7.66 & -7.53 & -6.73 & -9.00 & -8.28 & -10.50 \\
2 & -7.32 & -6.65 & -6.41 & -5.05 & -8.16 & -6.52 & -8.33 \\
\hline \multirow{2}{*}{ Lags } & US-NK & US-SK & US-CN & CN-NK & CN-SK & CN-US \\
\hline 1 & -7.42 & -8.04 & -7.09 & -9.89 & -8.85 & -7.21 \\
2 & -5.26 & -6.30 & -5.98 & -7.96 & -7.57 & -5.90 \\
\hline
\end{tabular}

Notes: Mackinnon approximate $p$-value for $\mathrm{z}(\mathrm{t})=0.0000$.

1 percent critical value: -3.48

The Results of AIC, BIC Statistics for VAR Models with Lags of 1 to 4

\begin{tabular}{lll}
\hline Lag & AIC & BIC \\
\hline 1 & 98.08 & 102.29 \\
2 & 98.65 & 105.91 \\
3 & 99.07 & 109.36 \\
4 & 99.46 & 112.81
\end{tabular}

Notes: This is interpreted as fit statistics that describe the improvement in the log-likelihood, penalized for the additional lags. Small values of this fit statistics are better.

Likelihood Ratio Test Results for Lag Length

\begin{tabular}{ccccc}
\hline Lag & LL & LR & df & P \\
\hline 0 & -8589.92 & & & \\
1 & -8483.14 & 213.56 & 169 & 0.011 \\
2 & -8363.1 & $240.08 \mathrm{a}$ & 169 & 0.000 \\
\hline
\end{tabular}

Note: a. Based on these results, two lags are chosen.

\section{Notes}

I appreciate helpful comments and advice from T. David Mason, James Meernik, and Amber Aubone, as well as from the journal editor and the anonymous reviewers. Please send all correspondence to yoonjh1116@korea.ac.kr.

1. Peace regime, in the context of the Korean peninsula, refers to a whole range of state-to-state relationships that are designed to promote security and 
cooperation in the Korean peninsula (Goodby 2006). In particular, it focuses on the managerial mechanism that includes principles, norms, institutions, process, and organizations that are required to convert armistice status to peaceful status (Kil 2006, 67). It does not necessarily mean a peaceful reunification of South and North Korea. Rather, it is a step that includes features that would promote that outcome. Therefore, it includes an agreement on reconciliation, alleviation of military tension between South and North Korea, phased reductions in armaments, freedom of intra-Korean travel, cooperation in the international arena, and economic cooperation.

2. The difference between this concern and that of the literature is that this possibility is related to triangular relations among the United States, North Korea, and South Korea rather than bilateral relations between the United States and North Korea. Therefore, the theoretical framework of triangular relationship and its application to the situation in the Korean peninsula is reviewed later.

3. This advantage is, in fact, related to the triangular relations among North Korea, South Korea, and the United States rather than bilateral relations between the United States and North Korea. The existence of triangular relations provides a reason to use another theoretical framework to analyze the situation in the Korean peninsula.

4. Trends in some of these scores over time are displayed as times series graphs in the next section to check the face validity of the data.

5. The definition of this variable is discussed later in this section.

6. The results of lag specification tests are in the Appendix.

7. For example, if the United States has a positive score, such as 3, toward North Korea while South Korea has a negative score, such as -5 , toward North Korea in a given month, it is considered a disparity between the United States and South Korea's foreign policy toward North Korea, and this variable is coded 1. In a similar vein, if both the United States and South Korea have positive scores, such as 6 and 7, it is regarded as policy coordination. In such cases, the variable is coded 0 .

8. According to the IDEA dataset collector, "An actor code of PRK/ROK (North Korea/ South Korea) simply means that the reference to Korea is generic (e.g., Korea today is peaceful) . . . it can refer to the peninsula as a whole." Therefore, this study uses that data as a measure of the overall level of peace in the Korean peninsula.

9. The differences between the variable PK and South-North dyads variables such as SK-NK or NK-SK are shown as a graph in Figure 1.

10. After examining the face validity of the data, the existence of unit roots is also tested as a diagnostic analysis. It is important to test the possibility of unit roots to determine whether an error correction mechanism is necessary. Without such a correction, the presence of unit roots in variables makes the results of Granger causality questionable (Brandt and Williams 2007, 50-55, 61). Testing for unit roots is conducted using the ADF (Augmented Dickey-Fuller) test. The results allow for rejection of the null hypothesis of the presence of a unit root for all variables at a 1-percent significance level. The results of the ADF test appear in the Appendix. 
11. The highest $R$-squared value is .34 for the North Korea toward China equation. It suggests that 34 percent of the variation in North Korea's behavior toward China is explained by the model. $R$-squared values for other equations are between .13 and .26 . The results indicate a reasonably good fit between the model presented here and the data, especially given that quantitative analyses of international relations tend to produce low $R$-squared values (Davies 2007).

12. This result is explained later in this section.

13. There are some other cases that show the ambiguity of which party is ultimately to blame for breaking agreements. However, the details of those cases are not discussed any further, because exploring which party is responsible for breaching negotiated agreements is not the main issue of this study.

\section{References}

Axelrod, Robert. 1984. The Evolution of Cooperation. New York: Basic Books. Bond, Doug, Joe Bond, Churl Oh, J. Craig Jenkins, and Charles Lewis Taylor. 2003. "Integrated Data for Events Analysis (IDEA): An Event Typology for Automated Events Data Development. Journal of Peace Research 40, 6: 733-745.

Boyle, Elizabeth Heger, and Edward J. Lawler. 1991. "Resolving Conflict Through Explicit Bargaining." Social Forces 69, 4: 1183-1204.

Brandt, Patrick T., and John T. Williams. 2007. Multiple Time Series Models. Thousand Oaks, CA: Sage Publications.

Bueno de Mesquita, Bruce, and David Lalman. 1992. War and Reason: Domestic and International Imperatives. New Haven: Yale University Press.

Carpenter, Ted, and Doug Bandow. 2004. The Korean Connundrum: America's Troubled Relations with North and South Korea. New York: Palgrave Macmillan.

Cha, V. D., and D. C. Kang. 2003. Nuclear North Korea: A Debate on Engagement Strategies. New York: Columbia University Press.

Davies, Graeme A. M. 2007. "Coercion or Engagement? A Quantitative Test of the Effect of Regional Actors on North Korean Behaviour 1990-2000." British Journal of Politics and International Relations 9, 3: 477-493.

Goldstein, Joshua S., and John R. Freeman. 1991. "U.S.-Soviet-Chinese Relations: Routine, Reciprocity, or Rational Expectations?" American Political Science Review 85, 1: 17-35.

Goldstein, Joshua S., and Jon C. Pevehouse. 1997. "Reciprocity, Bullying, and International Cooperation: Time Series Analysis of the Bosnia Conflict." American Political Science Review 91, 3: 515-529.

Goldstein, Joshua S., Jon C. Pevehouse, Deborah J. Gerner, and Shibley Telhami. 2001. "Reciprocity, Triangularity, and Cooperation in the Middle East, 1979-97." Journal of Conflict Resolution 45, 5: 594-620.

Goodby, James E. 2006. “Creating a Peace Regime in Korea.” Washington, DC: Brookings Institution. Available at www.brookings.edu/opinions/2006/0530 northkorea_goodby.aspx (accessed February 7, 2011). 
Greffenius, Steven, and Jungil Gill. 1992. "Pure Coercion vs. Carrot-and-Stick Offers in Crisis Bargaining." Journal of Peace Research 29, 1: 39-52.

Harrison, Selig. 2003. Turning Point in Korea: New Dangers and New Opportunities for the United States. Washington, DC: Center for International Policy.

—. 2005. "Did North Korea Cheat?" Foreign Affairs, January-February.

Huth, Paul, and Bruce Russett. 1990. "Testing Deterrence Theory: Rigor Makes a Difference." World Politics 42, 4: 496-526.

Kil, Byung-Ok. 2006. "Hanbando Pyunghwacheje Goochookgwa Nambookhyubryuk Baljunbangan" [Establishment of the Korean peace system and development plans for South-North cooperation]. Hankookgwa Gookjejungchi [Korean and international politics] 22 (Summer): 63-86.

Kolodziej, Edward A., and I. William Zartman. 1996. "Coping with Conflict: A Global Approach." In Coping with Conflict After the Cold War, ed. Edward A. Kolodziej and Roger E. Kanet, 3-34. Baltimore: Johns Hopkins University Press.

Larson, Deborah Welch. 1988. "The Psychology of Reciprocity in International Relations." Negotiation Journal 4 (July): 281-301.

Leng, Russell. 1984. "Reagan and the Russians: Crisis Bargaining Beliefs and the Historical Record." American Political Science Review 78, 2: 338-355.

Leng, R. J., and H. G. Wheeler. 1979. "Influence Strategies, Success, and War." Journal of Conflict Resolution 23: 655-684.

Moon, Chung-in. 2004. "North Korea's Foreign Policy in Comparative and Theoretical Perspective." In North Korea and the World: Explaining Pyongyang's Foreign Policy, ed. B. C. Koh, 355-368. Seoul: Kyungnam University Press.

. 2008. "Managing the North Korean Nuclear Quagmire: Capability, Impacts, and Prospects." In The United States and Northeast Asia: Debate, Issues, and New Order, ed. G. John Ikenberry and Chung-in Moon, 231-260. Lanham, MD: Rowman \& Littlefield.

Moore, William H. 1998. "Repression and Dissent: Substitution, Context, and Timing." American Journal of Political Science 42, 2: 851-873.

O'Hanlon, Michael, and Mike Mochizuki. 2003. Crisis on the Korean Peninsula: How to Deal with a Nuclear North Korea. New York: McGraw-Hill.

Osgood, Charles. 1962. An Alternative to War or Surrender. Champaign: University of Illinois Press.

Park, Han S. 2002. North Korea: The Politics of Unconventional Wisdom. Boulder: Lynne Rienner Publishers.

Patchen, Martin. 1987. "Strategies for Eliciting Cooperation from an Adversary: Laboratory and International Findings." Journal of Conflict Resolution 31: $164-185$.

Rubin, Jeffery Z., and Bert R. Brown. 1975. The Social Psychology of Bargaining and Negotiation. New York: Academic Press.

Russett, Bruce. 1983. The Prisoners of Insecurity: Nuclear Deterrence, the Arms Race, and Arms Control. San Francisco: W. H. Freeman.

Shellman, Steven M., Andrew Reeves, and Brandon Stewart. 2007. Fair and Balanced or Fit to Print? The Effects of Media Sources on Statistical Inferences. Athens: University of Georgia Press. 
Sigal, Leon. V. 1998. Disarming Strangers: Nuclear Diplomacy with North Korea. Princeton: Princeton University Press.

Sims, C. A. 1980. "Macroeconomics and Reality." Econometrica 48, 1: 1-48.

Snyder, Glenn, and Paul Diesing. 1977. Conflict Among Nations: Bargaining, Decision Making, and System Structure in the International Crisis. Princeton: Princeton University Press.

Snyder, Scott. 1999. Negotiating on the Edge: North Korean Negotiating Behavior. Washington, DC: United States Institute of Peace Press.

Tetlock, Phillip E. 1998. "Social Psychology and World Politics." In The Handbook of Social Psychology, vol. 2., ed. Daniel T. Gilbert, Susan T. Fiske, and Gardner Lindzey, 868-912. Boston: McGraw-Hill.

Zartman, I. William. 1997. The Structuralist Dilemma in Negotiation. Research on Negotiation in Organizations 6: 227-245. 


\section{The Park Chung Hee Era}

The Transformation of South Korea

\section{Edited by Byung-Kook Kim and Ezra F. Vogel}

"This remarkable book will establish itself as the most significant work on the Park period."

-Stephan Haggard, University of California San Diego

In 1959 South Korea was mired in poverty. By 1979 it had a powerful industrial economy and a vibrant civil society in the making, which would lead to a democratic breakthrough eight years later. The transformation took place during the years of Park Chung Hee's presidency. South Korea's political landscape under Park defies simple categorization. The nation was balanced uneasily between opposition forces calling for democratic reforms and the Park government's obsession with economic growth.

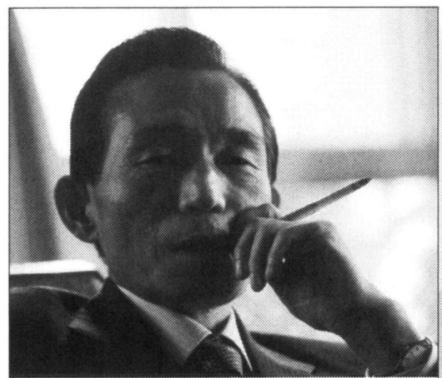
This landmark volume examines and contextualizes many of the ambiguities in South Korea's trajectory from poverty to a sustainable high rate of economic growth. new in cloth / \$55.00

The Park Chung Hee Era

The Transformation of South Korea

HARVARD UNIVERSITY PRESS

WWW HUP HARVARD.EDU

BLOG: HARVARDPRESSTYPEPAD.COM TEL 800.405 .1619 